\title{
Artemisinin potentiates apoptosis and triggers cell cycle arrest to attenuate malignant growth of salivary gland tumor cells
}

\author{
Peng Xiao', Qiujuan Liang², Qiuqiu Chen³ and Haixia Liu ${ }^{4}$ \\ 'Department of Stomatology, The Seventh Affiliated Hospital of Xinjiang Medical University, Urumqi 830028, Xinjiang, China; ${ }^{2}$ Department of \\ Stomatology, The Fifth Affiliated Hospital of Xinjiang Medical University, Urumqi 830000, Xinjiang, China; ${ }^{3}$ Department of Stomatology, \\ The Second Affiliated Hospital of Zhejiang University of Chinese Medicine, Hangzhou 310005, Zhejiang, China; ${ }^{4}$ Department of Stomatology, \\ Yangpu District Central Hospital of Shanghai (Yangpu Hospital Affiliated From Tongji University), Shanghai 200090, China
}

One of the rare malignant tumors developing within the glands of the buccal cavity in human beings is salivary gland tumors (SGTs). The hallmark of SGTs is the fusion of nuclear factor IB (NFIB) and myeloblastosis (MYB) genes developed after the translocation of q2223; p23-24. Although the aetiology of SGTs is not clear, however, the therapeutic modalities are surgical resection followed by the combination of chemotherapy and radiotherapy if a chance of recurrence seems to develop. Owing to have numerous side effects of chemotherapy, the drug development has been shifted to natural products with minimal side effects. One of the key phytochemical artemisinin derived from wormwood Artemisia annua exhibits various pharmacological activities against various in-vivo and in-vitro cellular models. Here, we evaluated the cytotoxic potential of artemisinin against A-253 cells with possible underlying cell death mechanisms. Our results showed that artemisinin reduces the proliferation of cells in a concentration-dependent manner and displays $I C_{50}$ value in a range of $10.23,14.21 \mu \mathrm{M}$, and 203.18 $\mu \mathrm{M}$ against A-253/HTB-41 and transformed salivary gland SMIE cells, respectively. Flow cytometry analysis demonstrated that artemisinin promotes a significant amount of apoptotic cellular population and triggers $G_{0} / G_{1}$ arrest of A-253 cells in a concentrationdependent manner. To verify the mechanism of cell death induced by artemisinin in A-253 cells, we found an increased level of Bax, Bim, Bad, Bak and reduced level of antiapoptotic protein $\mathrm{BCl}-2, \mathrm{BCl}_{\mathrm{XL}}$ with concomitant release of mitochondrial resident protein cytochrome $c$ into the cytoplasm. Additionally, we found that artemisinin augments the production of reactive oxygen species which further leads to the activation of proapoptotic proteins PARP1, and caspase- 3 , in a concentrationdependent manner thereby triggering apoptosis. In conclusion, artemisinin exhibits promising anticancer therapeutic potential against A-253 cells and needs further validation of in-vitro results in preclinical models.

Keywords: Artemisinin, apoptosis, salivary gland tumors, cell death, chemotherapy

Received: 31 August, 2021; revised: 21 October, 2021; accepted: 02 December, 2021; available on-line: 13 February, 2022

\section{凶e-mail: yzx505lhx@sina.com}

Acknowledgements of Financial Support: The current study was funded by an intramural grant from the Central Hospital of Shanghai

Abbreviations: SGTs, Salivary gland tumors; NFIB, nuclear factor IB; MYB, myeloblastosis; MTT, 3-(4, 5-dimethylthiazol-2-y1)-2, 5-diphenyltetrazolium bromide; DMEM, Dulbecco's modified Eagle's medium; FBS, fetal bovine serum;Pl, propidium iodide; PMSF, phenylmethylsulfonyl fluoride; DTT, dithiothreitol; DMSO, dimethyl sulfoxide; HRP, horseradish peroxidase; SDS-PAGE, sodium dodecylsulphate-polyacrylamide gel electrophoresis; PVDF, polyvinylidene fluoride; PBS, phosphate buffer saline; TBST, tris-buffered saline tween-20; PI3K/Akt, phosphoinositide 3-kinase/protein kinase B; Mcl-1, myeloid leukemia; Bcl-2, B-cell lymphoma; Bcl- $x_{L}$, B-cell lymphoma extra large; Bim, B-cell-like protein 11; Bak, Bcl-2 homologous antagonist/killer; Bax, Bcl-2 associated $x$ protein; ANT, adenine nucleotide translocator; VDAC, voltage-dependent anion channel; JC-1, 5,5,6,6'-tetrachloro-1,1'3,3'-tetrathylbenzimi-diazoylcarbocyanine iodide $(\mathrm{JC}-1) ; \mathrm{H}_{2} \mathrm{O}_{2}$, hydrogen peroxide; DCFHDA, 7'-dichlorofluorescein diacetate (DCFHDA); DAPI, 4,6-diamidino2-phenylindole; NAC, N-acetylcysteine; MMP, mitochondrial membrane potential

\section{INTRODUCTION}

Salivary gland tumors (SGTs) are a rare group of complex with heterogeneous histology that is developed from the parotid, sublingual, and submandibular glands of the buccal cavity (Namboodiripad, 2014). The striking feature of human SGTs is the translocation of q22-23, p23-24, a fusion of nuclear factor IB (NFIB), and myeloblastosis (MYB) proto-oncogenes located on chromosome 9p and 6q, respectively (Skálová et al., 2018). This fusion promotes the development of heterogeneity and resistance to available conventional therapies and often makes SGT's diagnosis, therapeutics, and prognosis worst (Wysocki et al., 2016). The treatments of choice in SGTs are the complete removal of primary lesions of glands affected with malignancies. The advanced rate of progression of metastatic SGTs often has a dismal prognosis with a survival period that ranges from 6 to 9 months (Adams et al., 2013). The recent reports suggest that the development of therapeutic resistance to SGTs was due to the upregulation of phosphoinositide 3-kinase/protein kinase B (PI3K/Akt) signaling pathway (Adams et al., 2015). This aberration of the PI3K/ Akt pathway promotes the upregulation of downstream mediators of antiapoptotic proteins (myeloid leukemiaMcl-1, B-cell lymphoma-Bcl-2, and B-cell lymphoma extra large-Bcl- $\mathrm{x}_{\mathrm{I}}$ ) and downregulation of proapoptotic proteins (B-cell-like protein 11-Bim, Bcl-2 homologous antagonist/killer-Bak, and Bcl-2 associated x protein-Bax) and supports the notion that high $\mathrm{Bcl}-2 / \mathrm{Bax}$ ratio could lead to poor prognosis in the salivary gland tumors (Xie et al., 1999, Pattingre et al., 2005). Recent data revealed that silencing of $\mathrm{Bcl}-2$ or blocking $\mathrm{Bcl}-2$ homology domain-3 (BH3) - a domain of proapoptotic proteins by mimetics in A-253 cells could be the ideal choice to deal with poor prognosis of salivary gland malignancies (Pattingre et al., 2005). 
The key hallmark of malignant cells is the development of resistance to programmed cell death. Therefore, augmentation of programmed cell death and attenuation of cellular growth by triggering cell cycle arrest is the primary aim of almost all anticancer therapeutics to kill malignant cells without eliciting inflammation (Viktorsson et al., 2005). One of the key cellular organelles, the mitochondria is critically important in dealing with intrinsic apoptosis and targeting mitochondria in malignant cells is the ideal choice for anticancer therapeutics (Leibowitz \& Yu, 2010). The striking feature of mitochondrial-dependent apoptosis is depolarisation of inner mitochondrial membrane potential with the concomitant discharge of mitochondrial resident and proapoptotic protein cytochrome $c$ into the cytosol (Wu \& Bratton, 2013). These events lead to the activation of caspase-9 which triggers the initiation of caspase activation thereby leading to condensation of DNA and eventually cell death. Additionally, loss of mitochondrial membrane potential (MMP) induces the formation of pores in an inner mitochondrial membrane by oligomerization of Bak/ Bax monomers to release cytochrome c for the execution of apoptosis (Wu \& Bratton, 2013). However, the antiapoptotic proteins function in reverse by interacting with proapoptotic proteins $\mathrm{Bax} / \mathrm{Bak}$ to inhibit the oligomerization of $\mathrm{Bak} / \mathrm{Bax}$ thereby preventing the execution of apoptosis (Wu \& Bratton, 2013).

Intracellular reactive oxygen species (ROS) are mainly produced by the mitochondrial electron transport chain (ETC) and play a dual role in promoting carcinogenesis signaling cascade or inducing cell death. An abrupt rise in intracellular ROS often culminates in the induction of pro-death signals in the tumor cells (Thangam et al., 2014). ROS regulate mitochondrial resident proteins such as adenine nucleotide translocator (ANT), voltagedependent anion channel (VDAC), and associated components of oxidative phosphorylation to promote loss of MMP or may modulate redox enzyme functions, thereby attenuating cellular antioxidant mechanisms to favour programmed cell death (Zorov et al., 2014). In contrast, tumor cells of various malignancies either have a low level of antioxidant activity or are deficient in one or more enzymes compared to normal cells to neutralize the reactive oxygen species (Yamamoto et al., 2003). Owing to having low antioxidant capacities or defective antioxidant enzymatic machinery in many malignant cells due to ROS (Ryter et al., 2007; Antosiewicz et al., 2008), we hypothesize that induction of ROS-mediated cell death in salivary gland tumor cells could be the ideal strategy to develop novel chemotherapeutics in SGTs.

In the recent past, natural compounds from plant sources received great attention in drug discovery programs against various types of cancers. Artemisinin a principle compound derived from Artemisia annua has been used long back in China as traditional medicine against various ailments such as antimalarial, anti-inflammation, immunomodulation, and antibacterial activity (Swargiary et al., 2020). Owing to having numerous medicinal properties, artemisinin exhibits promising antiproliferative and cell death-inducing potential in a wide variety of human cancer cell models both in vitro and in vivo settings (Jamalzadeh et al., 2017). Mechanistically, artemisinin attenuates tumor progression by induction of apoptosis, autophagy, and promotes antiangiogenic effect by inhibition of angiogenesis (Wong et al., 2017). Besides inhibition of PI3K/Akt signaling and nuclear factor kappa B (NF-xB) downregulation, artemisinin has been reported to promote ROS induction in cellular models (Wong et al., 2017). However, abrupt stimulation of
ROS, activation of pro-apoptotic activity, and cell cycle arrest by artemisinin in A-253 cells are unexplored.

Therefore, the current evaluation was aimed to investigate the antiproliferative, apoptotic-inducing, and cell cycle arrest by artemisinin against SGTCs (A-253/HTB41). Our results showed that artemisinin brings on the promising antiproliferative potential against A-253 cells. Mechanistically, we observe the loss of MMP, activation of apoptosis signaling with concomitant downregulation, and upregulation of $\mathrm{Bcl}-2 / \mathrm{Bcl}-\mathrm{x}_{\mathrm{L}}$ and $\mathrm{Bad} / \mathrm{Bax} / \mathrm{Bak} /$ Bim, respectively in A-253 cells exposed to the dosedependent treatment of artemisinin. Subsequently, we found dose-dependent cell cycle arrest at $G_{0} / G_{1}$ phase in A-253 cells. Additionally, we found abrupt induction of ROS generation in salivary gland tumor cells exposed to artemisinin which could further augment the mitochondrial-dependent apoptosis mechanism of artemisinin against A-253 cells.

\section{MATERIAL AND METHODS}

\section{Cell culture, reagents, and treatments}

Salivary gland tumor cell line (A-253/HTB-41) and normal transformed submandibular epithelial (SMIE) rat cells were procured from American Type Culture Collection (ATCC). The cell lines were cultured under aseptic conditions in respective McCoy's 5a, and Dulbecco's modified Eagle's (DMEM) culture medium obtained from Invitrogen. The cultured media were supplemented with L-glutamine, $10 \%$ fetal bovine serum, and $1 \%$ penicillin-streptomycin from Invitrogen to inhibit any bacterial growth. All the cells were timely checked for mycoplasma contamination. The artemisinin was obtained from Sigma-Aldrich and was dissolved in dimethyl sulphoxide (DMSO) to make a $20 \mathrm{mM}$ stock solution for experimentation. The artemisinin treatments to A-253 cells were dose-dependent $(10,20$, and $30 \mu \mathrm{M})$ for $24 \mathrm{~h}$.

\section{Chemicals and antibodies}

Propidium iodide (PI), artemisinin, 5,5,6,6'-tetrachloro-1,1',3,3'-tetrathylbenzimi-diazoylcarbocyanine iodide (JC-1), hydrogen peroxide $\left(\mathrm{H}_{2} \mathrm{O}_{2}\right)$, 3-(4,5-dimethylthiazol2-yl)-2, 5-diphenyltetrazolium bromide (MTT), staurosporine, dimethyl sulphoxide (DMSO), 7'-dichlorofluorescein diacetate (DCFHDA), 4',6-diamidino-2-phenylindole (DAPI), and N-acetylcysteine (NAC) were obtained from the Sigma-Aldrich. The required polyclonal primary antibodies (Bcl-2, Bax, Bim, Bak, cytochrome c, $\beta$-actin, PARP1, Bcl- $x_{\mathrm{L}}, \mathrm{Bcl}-2$, VDAC, and caspase-3) were purchased from the Cell Signaling Technology. The HRPconjugated rabbit and mouse IgG secondary antibodies were from Sigma-Aldrich.

\section{Cell viability assay}

The cell viability of A-253 cells was evaluated by the commonly used MTT assay (Rah et al., 2012). Briefly, $5 \times 10^{3}$ A-253 cells were seeded in each well of the 96well plate and incubated for more than $8 \mathrm{hr}$ to adhere properly to the plate surface. A-253 cells were treated with varying doses of artemisinin $(10,20$, and $30 \mu \mathrm{M})$ for $24 \mathrm{~h}$. After treatment, cells were exposed to $20 \mu \mathrm{L}$ $(2.5 \mathrm{mg} / \mathrm{mL})$ of MTT dye for 3-4 h. After the completion of incubation, $150 \mu \mathrm{L}$ of DMSO was added to dissolve formazan crystals. The color solution obtained after gentle shaking was measured at $570 \mathrm{~nm}$ by using a multiplate reader. The absorbance was recorded, and 
cell viability was determined as cell viability in an artemisinin-treated group to that of cell viability in the untreated control group.

\section{Quantification of an apoptotic population of cells}

The apoptotic cell population was quantified by flow cytometry as determined previously. (Alnuqaydan et al., 2020). Briefly, $5 \times 10^{5}$ A-253 cells were treated with artemisinin in a dose-dependent manner $(10,20$, and $30 \mu \mathrm{M})$ in a 6 -well plate for $24 \mathrm{~h}$ at $37^{\circ} \mathrm{C}$. After incubation, cells were harvested from each well, washed thrice with precooled PBS, and then resuspended in a binding buffer provided in the apoptosis detection kit (Sigma-Aldrich). The cells were then incubated with fluorescein isothiocyanate (FITC)-conjugated annexin $\mathrm{V}$ antibody $(5 \mu \mathrm{L})$ and PI $(5 \mu \mathrm{L})$ in dark at $4^{\circ} \mathrm{C}$ for $15 \mathrm{~min}$. Incubated samples containing suspended cells were operated and evaluated for quantification of apoptosis by flow cytometry (BD Bioscience).

\section{Cell cycle analysis}

Different stages of the cell cycle of A-253 cells after exposure to various doses of artemisinin (10, 20, and 30 $\mu \mathrm{M}$ ) were analyzed by using flow cytometry (Alnuqaydan and Rah 2021). Briefly, $0.5 \times 10^{6}$ A-253 cells were plated and exposed to various doses of artemisinin (10, 15, and $20 \mu \mathrm{M})$, camptothecin $(1 \mu \mathrm{M})$ as a positive control, and DMSO as untreated control. After $24 \mathrm{~h}$ treatment, cells were harvested, washed with pre-cooled phosphatebuffered saline (PBS), and then fixed at $-20^{\circ} \mathrm{C}$ with $70 \%$ ethanol overnight. After fixation, cells were subjected to RNAse $(100 \mu \mathrm{g} / \mathrm{mL})$ treatment for $30 \mathrm{~min}$ at $37^{\circ} \mathrm{C}$, followed by staining with propidium iodide $(50 \mu \mathrm{g} / \mathrm{mL})$ for another $30 \mathrm{~min}$ at $4^{\circ} \mathrm{C}$. Using the BDTM LSR II flow cytometry system, processed A-253 cells were analyzed and quantified in various phases of the cell cycle.

\section{Collection of cytosolic and mitochondrial fractions from A-253 for western blotting}

Cytosolic and mitochondrial fractions were collected as described previously (Rah et al., 2015a). After $24 \mathrm{~h}$ treatment of A-253 cells with artemisinin in a dose-dependent manner $(10,15$ and $20 \mu \mathrm{M})$, along with DMSO as untreated control, cells were scrapped/ trypsinized, harvested, and washed with ice-cooled PBS. The washed cells were incubated and resuspended in buffer A (1 mM dithiothreitol (DT'T), $200 \mathrm{mM}$ sucrose, $1 \mathrm{mg} / \mathrm{mL}$ bovine serum albumin (BSA), $1 \mathrm{mM}$ ethylene glycol-bis ( $\beta$-aminoethyl ether)-N,N,N',N'-tetraacetic acid (EGTA) and $10 \mathrm{mM} \mathrm{pH} 7.4$ Tris-MOPS) and were lysed by passing through 18-gauge syringe needle many times. The cell lysates in buffer A obtained were centrifuged $(0.1 \mathrm{~h}, 1000 \mathrm{~g})$ at $4-8^{\circ} \mathrm{C}$. The supernatants were again centrifuged $(15 \mathrm{~min}, 15000 \times \mathrm{g})$ at $4^{\circ} \mathrm{C}$ to separate mitochondria. The supernatants obtained after second centrifugation contained only cytosolic protein fraction and the pellet obtained contained mitochondrial fraction. The respective fractions thus obtained were subjected to Bradford analysis to measure protein concentration. After calculating the concentration of protein, $20-30 \mu \mathrm{g}$ of protein from both the fractions of all treatments were loaded in sodium dodecyl sulfatepolyacrylamide gel electrophoresis (SDS-PAGE) gel to resolve proteins based on molecular weight under the standard voltage $100 \mathrm{~V}$. Resolved proteins were transferred on to the PVDF membrane, followed by incubation of transferred polyvinylidene fluoride (PVDF) membrane with $5 \%$ skimmed milk as blocking solution in TBST to avoid any non-specific antibody binding. Incubation of PVDF membrane with primary antibody was performed either for 3-4 h at room temperature or for overnight at $4{ }^{\circ} \mathrm{C}$ on the shaker to ensure uniform binding of an antibody to the corresponding antigen. After incubation of PVDF membrane containing transferred proteins with antibodies solution (dilution 1:1000), PVDF membrane was washed with TBST for 5 min (3 times) and incubated with corresponding secondary antibodies (horseradish peroxidase-HRP-conjugated, dilution $1: 10000$ ) at $37^{\circ} \mathrm{C}$ for 1 to $1.5 \mathrm{~h}$. PVDF membranes were washed again with TBST for $5 \mathrm{~min}$ (3 times), cleaned, and incubated with ECL reagent to detect the presence of protein on the PVDF membrane by capturing fluorescence on the X-ray film or with chemiluminescence based gel doc.

\section{Reactive oxygen species detection and estimation by Dichloro-dihydro-fluorescein diacetate (DCFHDA) method}

The detection and estimation of ROS were evaluated by the DCFH-DA method (Eruslanov and Kusmartsev 2010). Briefly, $10^{5} \mathrm{~A}-253$ cells in a 6 -well plate were exposed with the artemisinin in a concentration-dependent manner $(10,15$, and $20 \mu \mathrm{M})$ in the presence or absence of $\mathrm{N}$-acetylcysteine (NAC) $(5 \mathrm{mM})$ and a positive control $\mathrm{H}_{2} \mathrm{O}_{2}$ and DMSO as untreated control for $24 \mathrm{~h}$ at $37^{\circ} \mathrm{C}$. After $24 \mathrm{~h}$ treatment, A-253 cells were washed with icecooled PBS followed by incubation with DCFH-DA dye for half an hour at $37^{\circ} \mathrm{C}$. After $30 \mathrm{~min}$ photographs of stained cells were captured with a fluorescent microscope and subsequently cell plates were analyzed by recording fluorescence at excitation wavelength $488 \mathrm{~nm}$ and emission wavelength $525 \mathrm{~nm}$.

\section{Evaluation of depolarization of mitochondrial membrane potential (MMP)}

The mitochondrial membrane potential of A-253 cells was analyzed by JC-1 staining (Clayton \& Shadel, 2014; Rah et al., 2015a). After seeding cells at a density of $5 \times 10^{5}$ in each well of 6 -well plate, A-253 cells were exposed to dose-dependent treatment with artemisinin $(10,15$, and $20 \mu \mathrm{M})$ and staurosporine as positive control and DMSO as untreated control at $37^{\circ} \mathrm{C}$. After $24 \mathrm{~h}$ incubation, cells were harvested, washed with pre-cooled PBS. The collected cells were processed for JC-1 staining at room temperature for $20 \mathrm{~min}$. The cells which have intact mitochondria exhibit bright red fluorescence whereas those cells which are in a process or undergo apoptosis have depolarization of MMP exhibit green fluorescence. The change in fluorescence (red/green) was used to determine the healthy versus depolarization MMP. The stained cell suspension was analyzed to quantify the MMP of the cell population exposed to various treatments of artemisinin by flow cytometry (BD Bioscience).

\section{Phase-contrast microscopy}

A-253 cells were seeded at a density of $0.5 \times 10^{5}$ cells in each well of a sterile 6-well plate. Cells were incubated for overnight to get properly adhered to at $37^{\circ} \mathrm{C}$ in a $5 \% \mathrm{CO}_{2}$ incubator. Next, A-253 cells were exposed to various doses of artemisinin (10, 15, and $20 \mu \mathrm{M})$, staurosporine $(25 \mathrm{nM})$ as a positive control, and DMSO as untreated control for $24 \mathrm{~h}$ at $37^{\circ} \mathrm{C}$. After completion of time point, A-253 cells were directly 

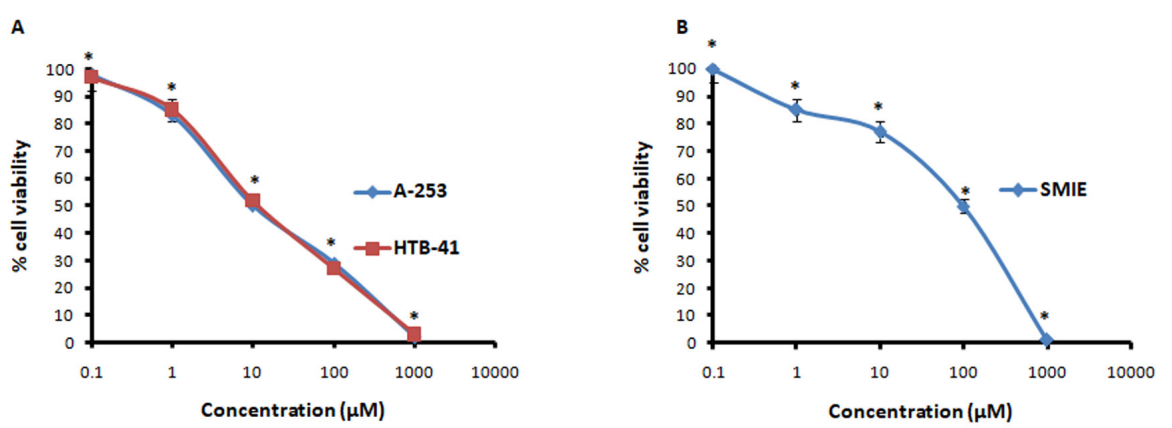

Figure 1. Evaluation of cell viability of cultured salivary gland tumor cells (A-253 cells).

(A) concentration-dependent inhibition of cell proliferation of A-253 cells after exposed to varying concentrations $(0.1,1,10,100,1000$, $10000 \mu \mathrm{M}$ ) of artemisinin. (B) Cell proliferation inhibition of transformed salivary gland cells (SMIE) in a concentration-dependent manner $(0.1,1,10,100,1000,10000 \mu \mathrm{M})$ with artemisinin. All the experiments were performed in triplicates $(n=3)$, each error bar designates the standard error of three independent experiments and is statistically significant $(p \leq 0.5)$.

analyzed by phase-contrast microscope (Nikon Eclipse TS100) by capturing photographs and analyzing the morphological changes induced by artemisinin.

\section{Statistical analysis}

The experimental data from the above experimental assays were performed more than three times and the data represent the mean \pm standard error of the mean (S.E.M.). The data from all experiments were calculated by using one-way ANOVA analysis. The $p$-value $\leq 0.05$ is taken as significant.

\section{RESULTS}

\section{Artemisinin reduces the proliferation of human A-253 cells in a concentration-dependent manner}

To evaluate the influence of artemisinin on cell viability, all the cell lines (A-253/HTB-41 and SMIE) seeded in 96-well sterile plates were exposed to varying doses of artemisinin $(0.1-100 \mu \mathrm{M})$ for $24 \mathrm{~h}$. We observed a dose-dependent reduction in cell viability in all the cell lines used in the MTT assay. When calculating the $\mathrm{IC}_{50}$ dose after $24 \mathrm{~h}$ exposure to artemisinin, we found $10.23 \pm 0.25 \mu \mathrm{M}$ for $\mathrm{A}-253$ and $14.21 \pm 0.38 \mu \mathrm{M}$ for HTB-41 cells (Fig. 1A). Intriguingly, we found quite a high $\mathrm{IC}_{50}$ value $(203.18 \pm 3.24 \mu \mathrm{M})$ against normal transformed human salivary gland SMIE cells (Fig. 1B). These results indicate that artemisinin specifically and significantly reduces the cell viability of human A-253 cells in comparison with normal SMIE cells.

Further, to support the reduction of cell viability by artemisinin, we perform phase-contrast microscopy to determine the morphological changes after artemisinin treatment. Upon dose-dependent exposure to artemisinin $(10,15$, and $20 \mu \mathrm{M})$ treatment and staurosporine $(25 \mathrm{nM})$ as a positive control for $24 \mathrm{~h}$ in A-253 cells, our phase-contrast microscopy results demonstrate that A-253 cells exposed to higher doses of artemisinin and positive control staurosporine $(25 \mathrm{nM})$ have altered morphology with a significant number of dead cells floating on the culture media (Fig. 2) compared to untreated control. Together, these data suggest that artemisinin is a promising antitumor natural compound that reduces the cell viability of A-253 cells significantly.

\section{Artemisinin promotes dose-dependent apoptosis and triggers $G_{0} / G_{1}$ cell cycle arrest in human A-253 cells}

Next, we tried to evaluate the underlying cell death mechanism induced by artemisinin in human A-253 cells. After exposure to artemisinin $(10,15$, and $20 \mu \mathrm{M})$ or staurosporine $(25 \mathrm{nM})$ as a positive control, and DMSO as untreated control at $37^{\circ} \mathrm{C}$ for $24 \mathrm{~h}$, cells were harvested and processed to determine the apoptotic cell population by flow cytometry. Our results revealed a dose-dependent induction of apoptosis caused by artemisinin in A-253 cells. The results showed that a substantial amount of population of apoptotic cells was induced $(12.87 \pm 1.03 \%, 17.86 \pm 1.35 \%$, and $24.74 \pm 1.97 \%)$ at varying doses of artemisinin $(10,15$, and $20 \mu \mathrm{M})$, respectively, compared to untreated control $5.82 \pm 0.07 \%$ in A-253 cells. Additionally, a significant induction of apoptosis $(39.8 \pm 3.3 \%$ ) was also observed in A-253 cells after
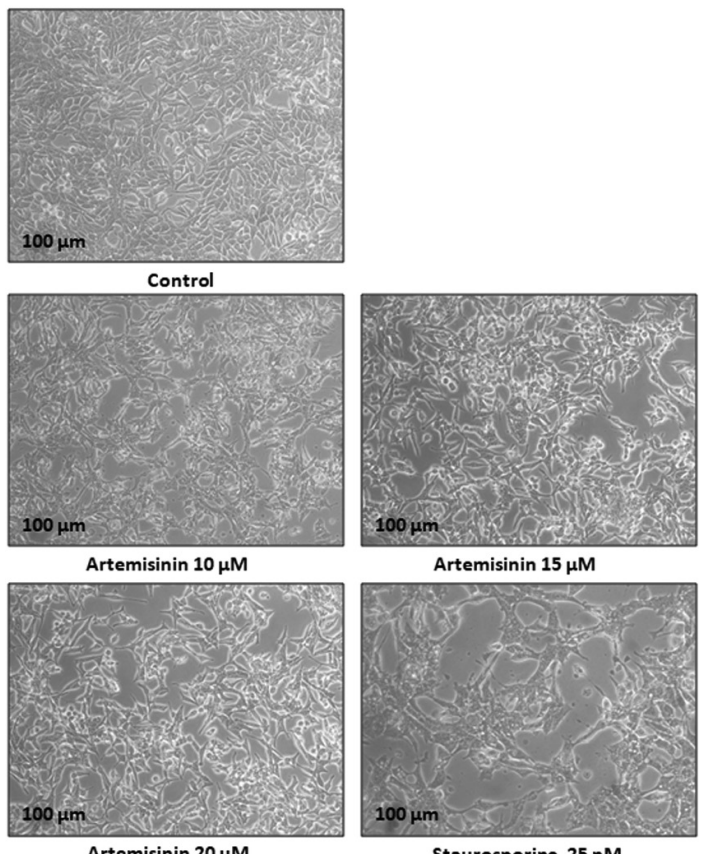

Figure 2. Morphological changes in A-253 cells after treatment with artemisinin.

A-253 cells exposed to varying doses of artemisinin (10, 15, $20 \mu \mathrm{M}$ ) along with positive control staurosporine $25 \mathrm{nM}$, and DMSO (less than 1\%) as untreated control to verify changes in cellular morphology of A-253 cells by phase-contrast microscope (Nikon Eclipse TS100). (Scale bars: $100 \mu \mathrm{m}$ ) 

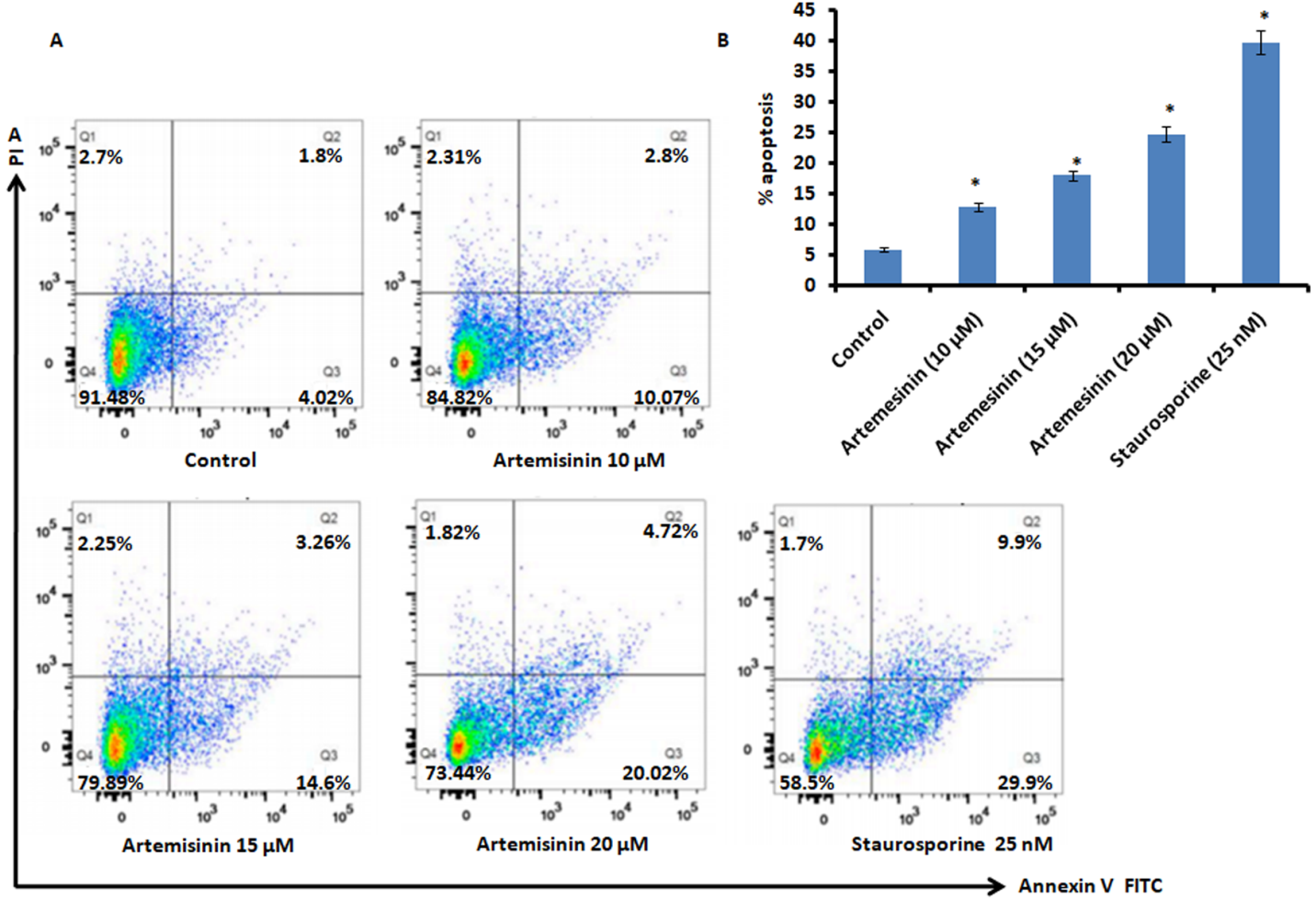

Figure 3. Artemisinin promotes dose-dependent apoptosis in A-253 cells.

C $\operatorname{Artemisinin}(10 \mu \mathrm{M})$ Artemisinin $(15 \mu \mathrm{M})$ Artemisinin $(20 \mu \mathrm{M})$ Staurosporine (25 $\mathrm{nM}$ )

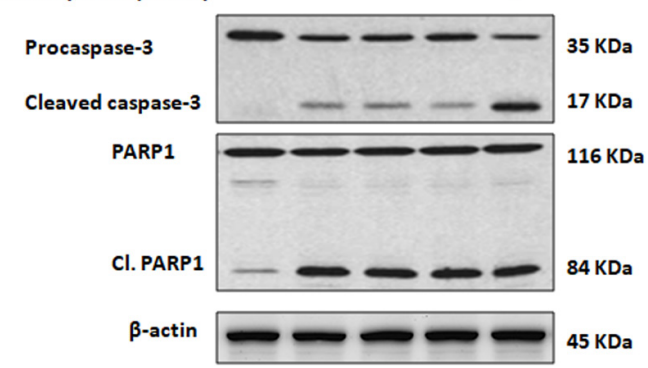

$24 \mathrm{~h}$ treatment with staurosporine $(25 \mathrm{nM})$ as a positive control (Fig. 3A and B).

Further, induction of apoptosis by dose-dependent treatment of cells with artemisinin was analyzed by western blotting to determine the protein level of activated apoptotic proteins. After dose-dependent treatment of A-253 cells with artemisinin (10,15 and $20 \mu \mathrm{M})$ and staurosporine $(25 \mathrm{nM})$ as a positive control, and DMSO as untreated control, for $24 \mathrm{~h}$ at $37^{\circ} \mathrm{C}$ cell lysates from different treatments of artemisinin were analyzed by western blotting to evaluate the protein level of apoptotic proteins. Immunoblotting findings demonstrated that at higher doses of artemisinin, A-253 cells showed the activation of proapoptotic Poly [ADP-ribose] polymerase 1 (PARP1) and caspase-3 protein forms into respective active products (Fig. 3C).

Additionally, we also used flow cytometry analysis to evaluate the influence of artemisinin on the cell cycle of A-253 cells. After exposure to artemisinin (10, 15, and $20 \mu \mathrm{M})$ and camptothecin $(1 \mu \mathrm{M})$ as positive control and DMSO as an untreated control at $37^{\circ} \mathrm{C}$ for $24 \mathrm{~h}$,
(A) Flow cytometry (BD Bioscience) analysis of apoptosis induced by varying doses of artemisinin $(10,15,20 \mu \mathrm{M})$ along with positive control staurosporine $25 \mathrm{nM}$, and DMSO (less than 1\%) as untreated control. The apoptotic cell population in quadrant Q2 and Q3 represents early and late apoptotic cells. The Q1 and Q4 quadrants represent necrotic and normal cell populations, respectively. (B) The bar chart represents the percentage of the apoptotic cell population (early and late) induced with indicated doses (10, 15, $20 \mu \mathrm{M}$ ) of artemisinin and positive control staurosporine $25 \mathrm{nM}$ after treatment of A-253 cells for $24 \mathrm{~h}$ at $37^{\circ} \mathrm{C}$. (C) Immunoblotting of A-253 cell lysates after treatment with indicated doses $(10,15$, $20 \mu \mathrm{M}$ ) of artemisinin along with positive control staurosporine $25 \mathrm{nM}$, and DMSO untreated control for $24 \mathrm{~h}$ at $37^{\circ} \mathrm{C}$ to verify the activation of proapoptotic proteins PARP1 and caspase- 3 to their respective cleaved products, and $\beta$-actin to ensure cell lysates was equally loaded. All the experiments were performed in triplicates $(n=3)$, each error bar designates the standard error of three independent experiments and is statistically significant $(p \leq 0.5)$.

A-253 cells were harvested and processed to determine the different phases of the cell cycle by flow cytometry. Our results of flow cytometry analysis revealed a dosedependent arrest of the $G_{0} / G_{1}$ cell cycle by artemisinin in A-253 cells. The results showed that a substantial part of the population of A-253 cells was arrested in the $G_{0} / G_{1}$ phase of the cell cycle $(54.57 \pm 1.03 \%$, $63.17 \pm 1.35 \%$, and $67.37 \pm 1.97 \%$ ) at varying doses of artemisinin $(10,15$ and $20 \mu \mathrm{M})$, respectively compared to positive control camptothecin $(1 \mu \mathrm{M})$ and untreated control are $74.27 \pm 1.34 \%$ and $47.56 \pm 0.07 \%$ in A-253 cells (Fig. 4A and 4B), respectively. Together these results suggest that artemisinin induces an antiproliferative effect in human A-253 cells by inducing apoptotic mechanism of cell death as well as $G_{0} / G_{1}$ cell cycle arrest in A-253 cells.

\section{Induction of apoptosis by artemisinin in A-253 cells is mitochondrial-dependent}

To evaluate the role of mitochondria in artemisinininduced apoptosis, we determined mitochondrial mem- 
A

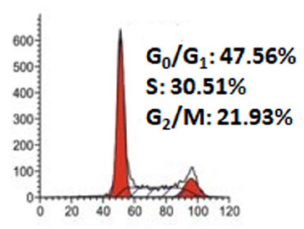

Control

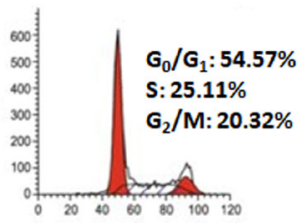

Artemisinin $10 \mu \mathrm{M}$

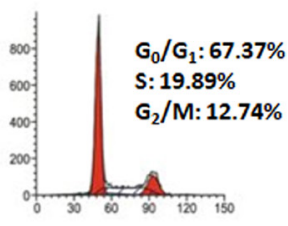

Artemisinin $20 \mu \mathrm{M}$

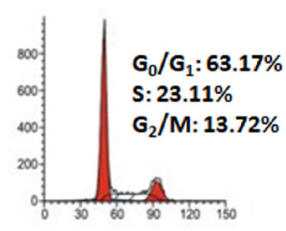

Artemisinin $15 \mu \mathrm{M}$

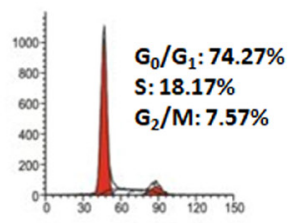

Camptothecin $1 \mu \mathrm{M}$
B

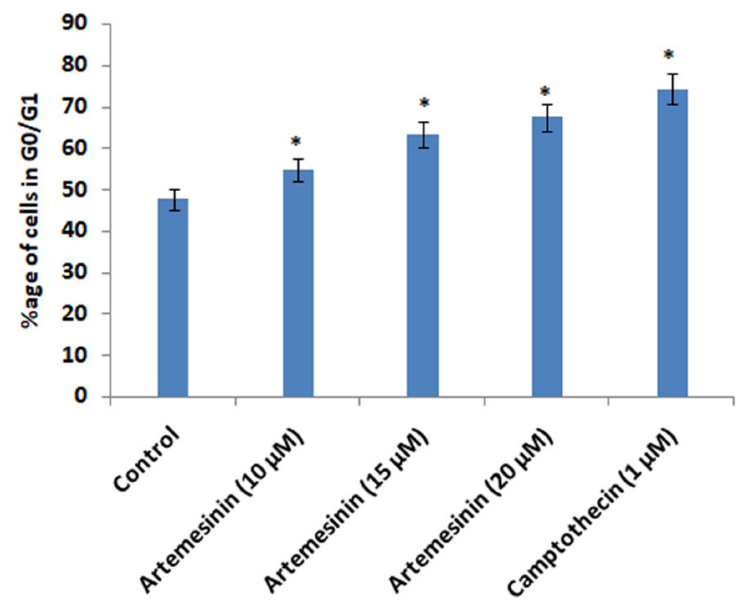

Figure 4. Evaluation of cell cycle analysis by flow cytometry of A-253 cells with dose-dependent artemisinin treatment

(A) Analysis of various cell cycle stages by flow cytometry after treatment with varying doses of artemisinin (10, $15,20 \mu \mathrm{M})$ along with positive control camptothecin $1 \mu \mathrm{M}$ and DMSO (less than 1\%) as untreated control to quantify the cells in different stages of the cell cycle in A-253 cells. (B) The bar chart represents the percentage of $\mathrm{G}_{0} / \mathrm{G}_{1}$ triggered cell cycle arrest with the indicated doses (10, 15, 20 $\mu \mathrm{M})$ of artemisinin and positive control camptothecin $1 \mu \mathrm{M}$ after treatment of $\mathrm{A}-253$ cells for $24 \mathrm{~h}$ at $37^{\circ} \mathrm{C}$. All the experiments were performed in triplicates $(n=3)$, each error bar designates standard error of three independent experiments and are statistically significant $(p \leq 0.5)$.

brane potential in artemisinin-treated A-253 cells. The A-253 cells were exposed to various doses of artemisinin $(10,15$, and $20 \mu \mathrm{M})$ and staurosporine $(25 \mathrm{nM})$ as a positive control, DMSO as untreated control for $24 \mathrm{~h}$. The A-253 cells were processed and stained with JC-1 dye to evaluate $\psi$ MMP by flow cytometry analysis. Our findings demonstrate a significant loss of $\psi M M P(76.72 \pm 0.83 \%$, $84.32 \pm 1.21 \%$, and $93.14 \pm 1.71 \%$ ) corresponding to 10,15 and $20 \mu \mathrm{M}$ artemisinin concentrations respectively, compared to DMSO control cells $(09.14 \pm 0.71 \%)$. The A-253 cells treated with $25 \mathrm{nM}$ staurosporine (positive control) presented a significant loss of $\psi \mathrm{MMP}$ (96.74 $\pm 3.31 \%)$ (Fig. 5A and B).

The loss of 4 MMP promotes disruption of the inner mitochondrial membrane causing the release of mitochondrial resident protein cytochrome $c$ into the cytoplasm (Madungwe et al., 2018). To check whether cytochrome $c$ is released after depolarization of mitochondrial membrane potential of A-253 cells by varying doses of artemisinin we performed subcellular fractionation followed by immunoblotting of both cytosolic and mitochondrial fractions. Our immunoblotting results demonstrated that the level of cytochrome $c$ in cytosolic fraction increases as the doses of artemisinin increase and concomitantly the level of cytochrome $c$ in mitochondrial fractionation decreases as the treatment dose of artemisinin increases. Intriguingly, we observed an increased level of proapoptotic proteins Bax, Bim, Bad, and Bak in mitochondrial fraction than in a cytosolic fraction (Fig. 5C). These data indicate that loss of $4 \mathrm{MMP}$ induced by artemisinin was augmented by Bax, Bim, Bad, and Bak to form pores in the outer mitochondrial membrane thereby allowing free movement to the mitochondrial resident protein cytochrome $\mathrm{c}$ to form apoptosome and execute mitochondrial-dependent apoptosis in A-253 cells.

\section{Induction of ROS by artemisinin augments mitochondrial-dependent apoptosis in A-253 cells}

Induction of ROS such as hydrogen peroxide $\left(\mathrm{H}_{2} \mathrm{O}_{2}\right)$ and $\mathrm{O}_{2} \bullet$ - implicates both cell survival as well as cell death depending upon the level of induction. Artemisinin has been reported to induce ROS production in various cellular models (Chong \& Zheng, 2016). Therefore, we determined the ROS production by artemisinin treatment in A-253 cells and whether the artemisinin-mediated ROS production in A-253 cells helps in cell survival or favours cell death. After dose-dependent treatment of A-253 cells with artemisinin $(10,15$ and $20 \mu \mathrm{M})$ along with the presence of ROS inhibitor NAC (5 mM) (Halasi et al., 2013), ROS inducer hydrogen peroxide $\left(\mathrm{H}_{2} \mathrm{O}_{2}\right)(100 \mu \mathrm{M})$ as a positive control (Wu et al., 2018), and DMSO as untreated control for $24 \mathrm{~h}$. The cells were processed for DCFH-DA staining to measure the intracellular ROS production by oxidizing and converting DCFH-DA dye to green fluorescent DCF probe and the intensity of green fluorescent is directly proportional to oxidative stress induced by ROS (Nayak \& Mishra, 2020). Recent reports suggest that various natural compounds promote antiproliferative effects by inducing ROS production in various cancer cell models (NavaneethaKrishnan et al., 2019, Şoica et al., 2020). Consistent with previous studies, our results showed that artemisinin abruptly induces ROS production, and the level of ROS production increases as the dose of artemisinin increases. We found a 1.7 to 
A

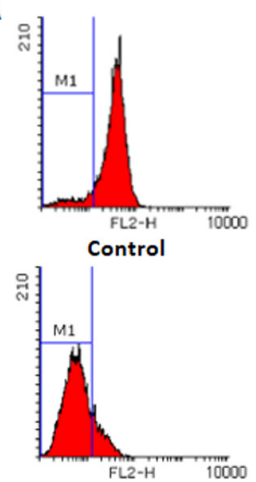

Artemisinin $15 \mu \mathrm{M}$

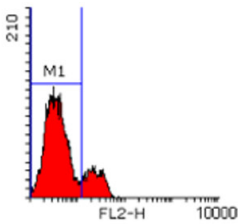

Artemisinin $10 \mu \mathrm{M}$

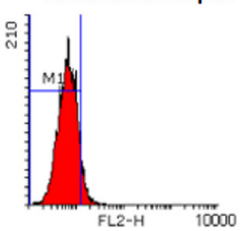

Artemisinin $20 \mu \mathrm{M}$

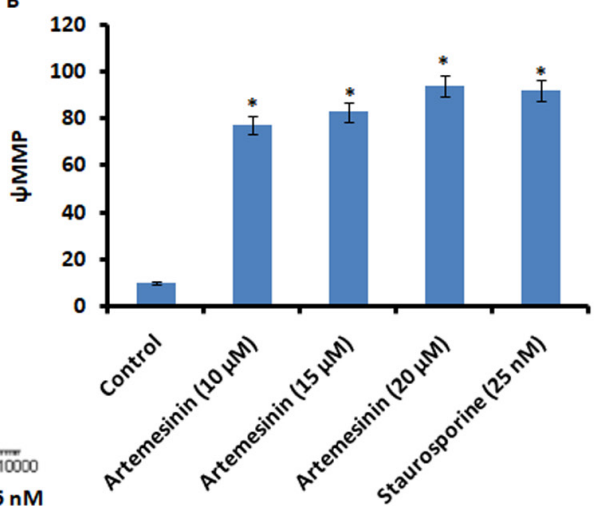

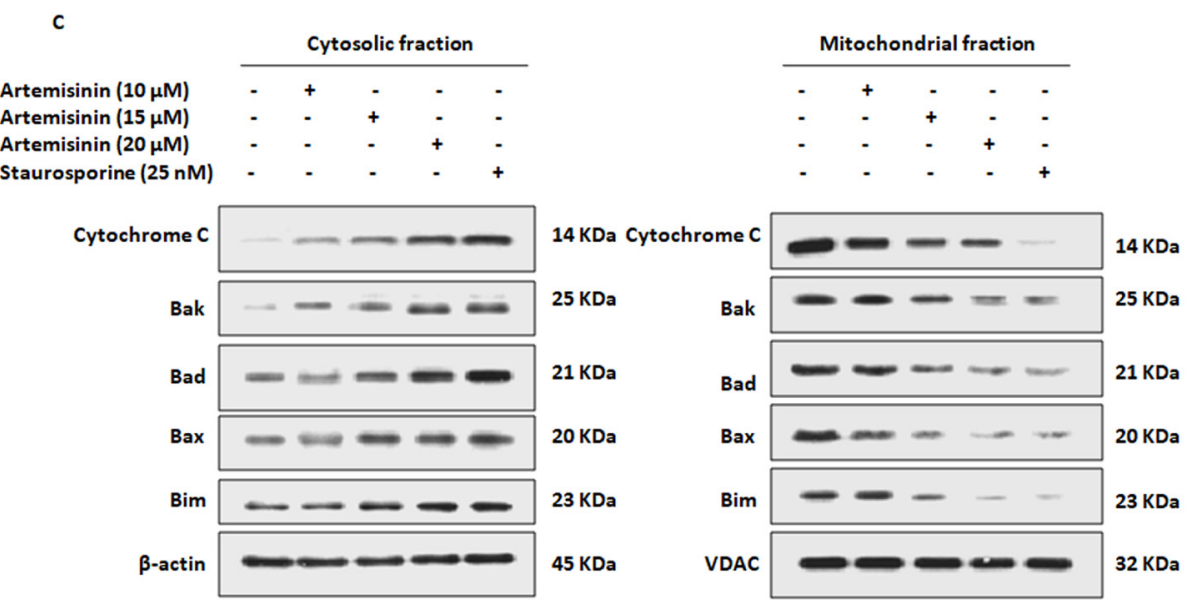

Cytosolic fraction

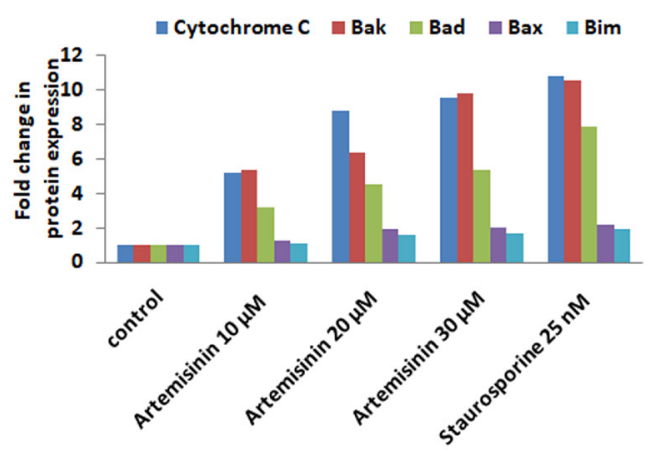

Mitochondrial fraction

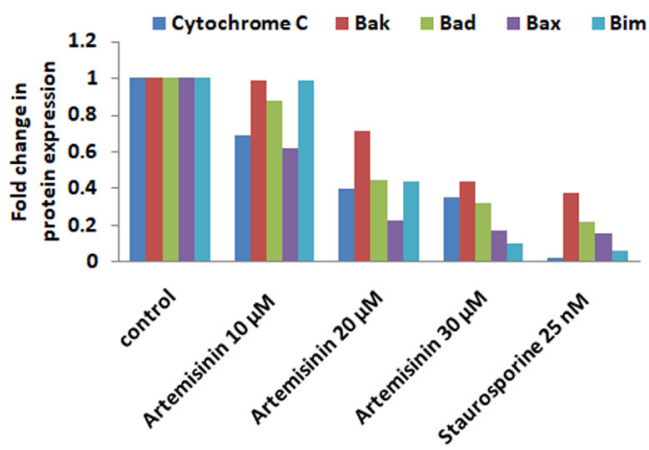

Figure 5. Evaluation of mitochondrial membrane potential ( $\Psi \mathrm{MMP}$ ) in artemisinin treated A-253 cells.

(A) Analysis of loss of $\Psi$ MMP by flow cytometry induced by varying doses of artemisinin $(10,15,20 \mu M)$ along with positive control staurosporine $25 \mathrm{nM}$ and DMSO (less than 1\%) as untreated control to quantify the JC-1 staining cell population (B) Bar chart represents the percentage JC-1 staining cells with depolarization of mitochondrial membrane potential after exposed with indicates doses (10, 15, $20 \mu \mathrm{M}$ ) of artemisinin and positive control staurosporine $25 \mathrm{nM}$ after treatment of A-253 cells for $24 \mathrm{~h}$ at $37{ }^{\circ} \mathrm{C}$. (C) Immunoblotting of A-253 cell lysates after treatment with indicates doses $(10,15,20 \mu \mathrm{M})$ of artemisinin along with positive control staurosporine $25 \mathrm{nM}$ and DMSO untreated control for $24 \mathrm{~h}$ at $37^{\circ} \mathrm{C}$ to verify the depolarization of mitochondrial membrane potential by analyzing various mitochondrial resident proteins cytochrome c, Bim, Bad, Bak, and Bax in cytosolic and mitochondrial fractions. (D) The histogram represents the fold change of protein expression of mitochondrial resident proteins in the cytosolic and mitochondrial fraction after normalizing with respective constitutive proteins $\beta$-actin and VDAC, respectively. All the experiments were performed in triplicates ( $n=3$ ), each error bar designates the standard error of three independent experiments and is statistically significant $(p \leq 0.5)$.

9.3-fold increase in ROS level in the dose-dependent treatment of A-253 cells exposed artemisinin when compared to untreated control. $\mathrm{H}_{2} \mathrm{O}_{2}$ exposed cells presented 7-times higher ROS levels than untreated control cells. Additionally, cells exposed to a higher dose of artemisinin $(20 \mu \mathrm{M})$ followed by treatment with NAC have a 1.1-fold higher intracellular ROS level than untreated control (Fig. 6A and B). Further, the report suggests that ROS production by natural compound with aferin A facilitates mitochondrial-dependent cell killing in colorectal cancer cells (Xia et al., 2018). Additionally, prenylated isoflavone auriculasin derived from F. philippinensis promotes ROS induction in prostate cancer cells thereby activating apop- 


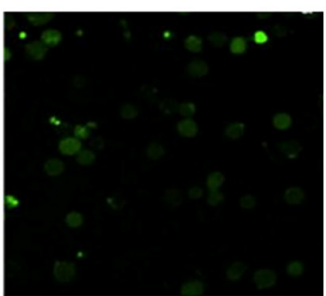

Control

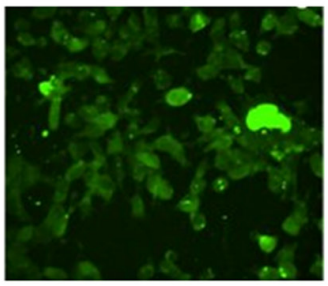

Artemisinin $15 \mu \mathrm{M}$

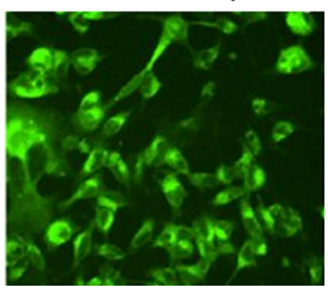

Hydrogen peroxide $\left(\mathrm{H}_{2} \mathrm{O}_{2}, 100 \mu \mathrm{M}\right)$

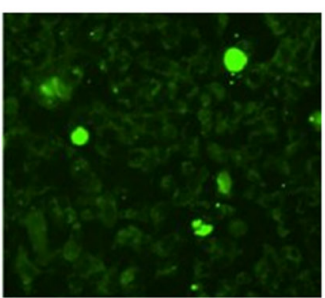

Artemisinin $10 \mu \mathrm{M}$

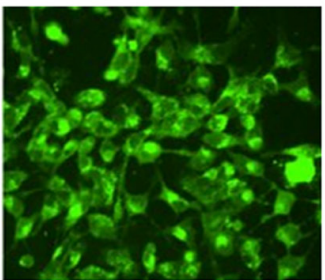

Artemisinin $20 \mu \mathrm{M}$

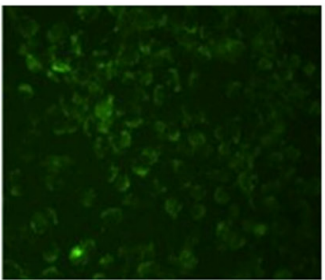

Artemisinin $20 \mu \mathrm{M}+$

$\mathrm{N}$-acetylcysteine (NAC, $5 \mathrm{mM}$ )

B

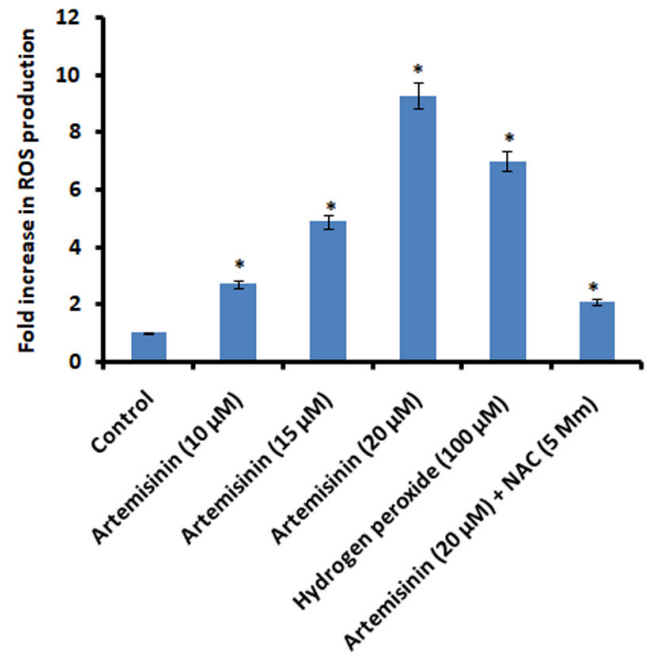

c

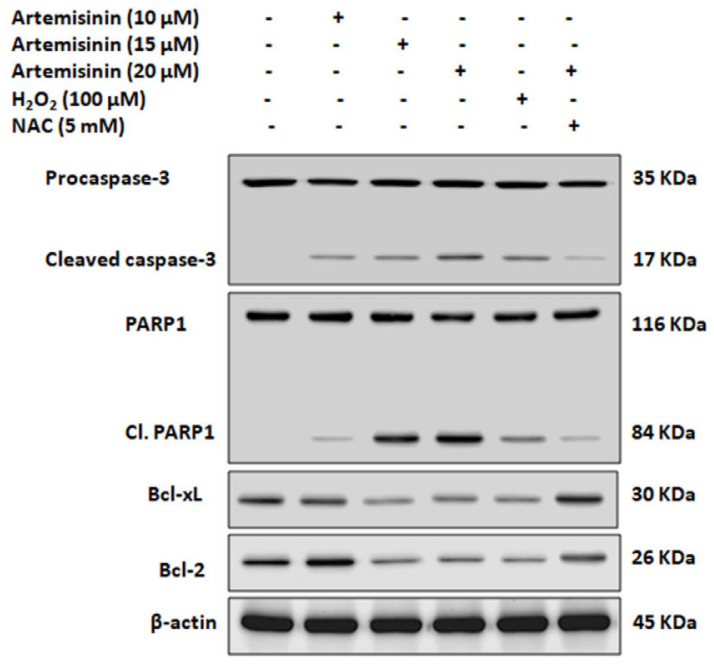

tosis (Cho et al., 2018). Consistent with these reports, we observed that artemisinin induces ROS production in A-253 cells thereby promoting apoptosis. Further, our immunoblotting results revealed that activation of proapoptotic proteins PARP-1 and caspase-3 were observed with a concomitant reduction in the protein level of antiapoptotic $\mathrm{Bcl}-2$ and $\mathrm{Bcl}_{\mathrm{L}}$ after A-253 cells at higher doses of artemisinin for $24 \mathrm{~h}$ (Fig. 6C). Intriguingly, pre-treatment of cells with a higher dose of artemisinin $(20 \mu \mathrm{M})$ followed by $\mathrm{N}$-acetylcysteine treatment, does not activate PARP-1, and caspase-3 proapoptotic proteins with the negligible decrease in antiapoptotic proteins $\mathrm{Bcl}-\mathrm{x}_{\mathrm{L}}$ and $\mathrm{Bcl}-2$ were observed (Fig. 6C). These data suggest that artemisinin promotes abrupt ROS production which further augments the artemisinin-induced apoptosis in A-253 cells.
Figure 6 Evaluation of reactive oxygen species (ROS) in artemisinin treated A-253 cells.

(A) Analysis of ROS estimation by microscopic method induced by varying doses of artemisinin $(10,15,20 \mu \mathrm{M})$ along with positive control hydrogen peroxide $100 \mu \mathrm{M}$, negative control NAC 5 $\mathrm{mM}$ and DMSO (less than 1\%) as untreated control to quantify the DCFD-HA staining cell population (B) Bar chart represents the fold change in DCFD-HA staining of cells with indicates doses $(10,15$, $20 \mu \mathrm{M}$ ) of artemisinin and positive control hydrogen peroxide 100 $\mu \mathrm{M}$ after treatment of A-253 cells for $24 \mathrm{~h}$ at $37^{\circ} \mathrm{C}$. (C) Immunoblotting of A-253 cell lysates after treatment with indicates doses $(10,15,20 \mu \mathrm{M})$ of artemisinin along with positive control hydrogen peroxide $100 \mu \mathrm{M}$, negative control NAC $5 \mathrm{mM}$ and DMSO untreated control for $24 \mathrm{~h}$ at $37^{\circ} \mathrm{C}$ to further verify the activation of proapoptotic proteins PARP1 and caspase- 3 and downregulation of antiapoptotic proteins $\mathrm{BCl}_{-\mathrm{XL}}$ and $\mathrm{BCl}-2$. Constitutive protein $\beta$-actin is also analyzed to ensure cell lysates were equally loaded. All the experiments were performed in triplicates $(n=3)$, each error bar designates the standard error of three independent experiments and is statistically significant $(p \leq 0.5)$.

\section{DISCUSSION}

One of the key mechanisms to prevent tumorigenesis is the execution of apoptosis to malignant cells (Rah et al., 2016). Most chemotherapeutic drugs in response to death signals generated within the cells by DNA damage or oncogenic activation promote apoptosis induction (Nayak et al., 2015; Rah et al., 2015b). Numerous chemotherapeutic drugs activate mitochondrial membranedependent apoptosis and often crosstalk with extrinsic apoptosis pathways to promote an effective mode of cell death to tumor cells (Sharma et al., 2012; Sinha et al., 2013; ur Rasool et al., 2016). In response to apoptotic stimuli, the striking feature of the internal (mitochondrial-dependent) apoptotic pathway is the release of mitochondrial resident proteins into the cytoplasm (Alnuqaydan et al., 2020) such as cytochrome $c$ which pro- 
motes initiation of apoptosome formation thereby activating other proapoptotic proteins such as caspase-3, -9, etc to activate apoptosis (Mignotte \& Vayssiere, 1998). Previous reports suggested that numerous natural compounds could induce cell death mechanisms in tumor cells by activating mitochondrial-dependent apoptosis. Rigo and Vinante (Rigo \& Vinante, 2016) demonstrated that $\alpha$-Bisabolol promotes intrinsic apoptosis cell death in tumor cells both in a concentration-dependent as well as time-dependent manner. Further, the study reveals that induction of cell death was due to loss of ४MMP. Consistent with these studies our results demonstrated that dose-dependent exposure of A-253 cells to artemisinin promotes significant loss of mitochondrial membrane potential. This was evidenced by the release of cytochrome $c$ and other prominent mitochondrial resident proteins such as Bim, Bad, Bak, and Bax into the cytosolic fraction (Fig. 5C and 5D).

Anticancer drugs kill tumor malignant cells mainly by apoptosis as well as trigger cell cycle arrest to attenuate the tumor cell growth (Zilla et al., 2014; Dar et al., 2018; Alnuqaydan et al., 2020). Luo and others (Luo et al., 2018) showed that a 6-Gingerol promotes apoptosis and subsequently triggers cell cycle arrest of gastric carcinoma cells to reduce the growth of malignant cells (Luo et al., 2018). Another similar study suggests that artemisinin interrupts transcriptional factor $\mathrm{E} 2 \mathrm{~F}$ thereby triggering G1 phase cell cycle arrest in breast cancer (MCF-7) cells (Tin et al., 2012). Consistent with previous results, our cell cycle analysis demonstrates that artemisinin induces $\mathrm{G}_{0} / \mathrm{G}_{1}$ phase cell cycle arrest in A-253 cells in a dosedependent manner.

Generation of intracellular ROS by dose-dependent treatment of artemisinin seems upstream incident of the mitochondrial-dependent apoptosis in A-253 cells. This is evidenced by the significantly reduced apoptotic population of A-253 cells that are pre-treated with artemisinin followed by NAC $(5 \mathrm{mM})$ treatment for $24 \mathrm{~h}$. Previous reports suggest that artemisinin induces apoptosis in various cellular models through different cell death cascade mechanisms (Gao et al., 2011). However, our results suggest that induction of ROS generation by artemisinin in A-253 cells could be an early event, and as the treatment time proceeds the generation of ROS could further augment the artemisinin-induced apoptosis in A-253 cells. The explanation for the high induction of apoptosis by artemisinin could be due to low or defect in one or more enzymes that promote antioxidant activity in A-253 cells. Artemisinin a natural phytochemical compound that possesses prooxidant activity further weakens the antioxidant system of salivary gland tumor cellular models thereby inducing ROS generation that promotes cell death mechanism in A-253 cells.

An antiapoptotic mechanism is mainly contributed by elevated $\mathrm{Bcl}-\mathrm{x}_{\mathrm{L}}$ and Bcl-2 levels in cells and thus contributes to chemoresistance (Choudhary et al., 2015). Whether these antiapoptotic proteins could have any role in SGT metastasis is not yet clear. To investigate whether the expression of key antiapoptotic proteins $\mathrm{Bcl}-\mathrm{x}_{\mathrm{L}}$ and Bcl-2 are elevated in A-253/ HTB-41 cells to drive them towards the development of drug resistance. We intended to correlate the level of antiapoptotic and apoptotic proteins of untreated and artemisinin-treated A-253 cells in the current study. We found a substantial decrease in the protein level of antiapoptotic $\mathrm{Bcl}-\mathrm{x}_{\mathrm{L}}$ and $\mathrm{Bcl}-2$ with concomitant upregulation and activation of proapoptotic proteins PARP-1, and caspase-3 in A-253 cells exposed with dose-dependent treatment with artemisinin. Additionally, previous studies revealed that a combination of chemotherapeutic drugs could sensitize malignant cells to cell death often frequently by modulating the relative ratio of various proapoptotic and antiapoptotic Bcl-2 families of proteins (Tagscherer et al., 2008). Upregulation of $\mathrm{Bcl}-2$ and $\mathrm{Bcl}-\mathrm{xL}$ antiapoptotic protein prevents the apoptotic activity of proapoptotic Bim, Bad, Bax, and Bak proteins by influencing the ratio of proapoptotic to antiapoptotic proteins (Kang \& Reynolds, 2009). Further, the ectopic level of Bcl-2 in leukemia cells prevents apoptosis significantly by modulating the proapoptotic and antiapoptotic protein level by artemisinin (Kim et al., 2013; Kumar et al., 2017). Consistent with earlier results (Ho et al., 2014; Wang et al., 2019), we found that artemisinin treatment of A-253 cells for $24 \mathrm{~h}$ modulates the proapoptotic to antiapoptotic protein ratio in favour of apoptosis activation by upregulating and downregulating the protein level of Bim, Bad, Bax, Bak and $\mathrm{Bcl}-2$ and $\mathrm{Bcl}-\mathrm{x}_{\mathrm{L}}$, respectively.

In conclusion, our results demonstrate that artemisinin exhibits a promising antiproliferative effect against A-253 cells at low micromolar doses. Mechanistically, artemisinin promotes ROS-mediated mitochondrialdependent apoptotic cell death and triggers $G_{0} / G_{1}$ cell cycle arrest. This was evidenced by loss of $\psi M M M P$, the liberation of cytochrome $c$ from the inner membrane of mitochondria, caspase cascade activation, and downregulation of antiapoptotic $\mathrm{Bcl}-\mathrm{x}_{\mathrm{L}}$ and $\mathrm{Bcl}-2$. Owing to having either low antioxidant activity or having a defective antioxidant system in malignant cells compared to normal cells, the artemisinin could be used in combination with other prooxidant drugs against salivary gland tumors to promote ROS-mediated cell death specifically in salivary gland tumor cellular models.

\section{Acknowledgments}

The author's thanks to the Department of Stomatology, Yangpu District Central Hospital of Shanghai for their technical support.

\section{Authors contributions}

Peng Xiao performs conceptualization, data curation, visualization, and formal analysis. Qiujuan Liang helps in manuscript writing, conceptualization, and review editing. Qiuqiu Chen performs and designs experiments, Haixia Liu conceptualization, writing, editing, and making an original draft of the manuscript.

\section{Conflict of Interest}

The authors declare no conflict of interest

\section{REFERENCES}

Adams A, Warner K, Nör JE (2013) Salivary gland cancer stem cells. Oral Oncol 49: 845-853. https://doi.org/10.1016/j.oraloncology.2013.05.013

Adams A, Warner K, Pearson AT, Zhang Z, Kim HS, Mochizuki D, Basura G, Helman J, Mantesso A, Castilho RM (2015) ALDH/ CD44 identifies uniquely tumorigenic cancer stem cells in salivary gland mucoepidermoid carcinomas. Oncotarget 6: 26633. https://doi. org/10.18632/oncotarget.5782

Alnuqaydan AM, Rah B (2021) Tamarix articulata Inhibits cell proliferation, promotes cell death mechanisms and triggers G0/G1 cell cycle arrest in hepatocellular carcinoma cells. Food Technol Biotechnol 59: 162-173. https://doi.org/10.17113/ftb.59.02.21.6904

Alnuqaydan AM, Rah B, Almutary AG, Chauhan SS (2020) Synergistic antitumor effect of 5-fluorouracil and withaferin-A induces endoplasmic reticulum stress-mediated autophagy and apoptosis in colorectal cancer cells. Am J Cancer Res 10: 799

Antosiewicz J, Ziolkowski W, Kar S, Powolny AA, Singh SV (2008) Role of reactive oxygen intermediates in cellular responses to di- 
etary cancer chemopreventive agents. Planta Medica 74: 1570-1579. https://doi.org/10.1055/s-2008-1081307

Cho H-D, Lee J-H, Moon K-D, Park K-H, Lee M-K, Seo K-I (2018) Auriculasin-induced ROS causes prostate cancer cell death via induction of apoptosis. Food Chem Toxicol 111: 660-669. https://doi. org/10.1016/j.fct.2017.12.007

Chong C-M, Zheng W (2016) Artemisinin protects human retinal pigment epithelial cells from hydrogen peroxide-induced oxidative damage through activation of ERK/CREB signaling. Redox Biol 9: 50-56. https://doi.org/10.1016/j.redox.2016.06.002

Choudhary GS, Al-Harbi S, Mazumder S, Hill BT, Smith MR, Bodo J, Hsi ED, Almasan A (2015) MCL-1 and BCL-xL-dependent resistance to the BCL-2 inhibitor ABT-199 can be overcome by preventing PI3K/AKT/mTOR activation in lymphoid malignancies. Cell Death Dis 6: e1593-e1593. https://doi.org/10.1038/cddis.2014.525

Clayton DA, Shadel GS (2014) Isolation of mitochondria from cells and tissues. Cold Spring Harbor Protocols 2014: pdb. top074542. https://doi.org/10.1101/pdb.top074542

Dar AM, Rah B, Mir S, Nabi R, Gatoo MA, Mashrai A, Khan Y (2018) DNA binding, artificial nuclease activity and cytotoxic studies of newly synthesized steroidal pyrimidines. Int J Biol Macromol 111: 52-61. https://doi.org/10.1016/j.ijbiomac.2017.12.128

Eruslanov E, Kusmartsev S (2010) Identification of ROS using oxidized DCFDA and flow-cytometry. In Advanced protocols in oxidative stress II. Springer, 57-72. https://doi.org/10.1007/978-1-60761411-1_4

Gao N, Budhraja A, Cheng S, Liu E-H, Huang C, Chen J, Yang Z, Chen D, Zhang Z, Shi X (2011) Interruption of the MEK/ERK signaling cascade promotes dihydroartemisinin-induced apoptosis in vitro and in vivo. Apoptosis 16: 511-523. https://doi.org/10.1007/ s10495-011-0580-6

Halasi M, Wang M, Chavan TS, Gaponenko V, Hay N, Gartel AL (2013) ROS inhibitor N-acetyl-L-cysteine antagonizes the activity of proteasome inhibitors. Biochem J 454: 201-208. https://doi. org/10.1042/BJ20130282

Ho WE, Peh HY, Chan TK, Wong WF (2014) Artemisinins: pharmacological actions beyond anti-malarial. Pharmacol Therapeutics 142: 126-139. https://doi.org/10.1016/j.pharmthera.2013.12.001

Jamalzadeh L, Ghafoori H, Aghamaali M, Sariri R (2017) Induction of apoptosis in human breast cancer MCF-7 cells by a semi-synthetic derivative of artemisinin: a caspase-related mechanism. Iranian J Biotechnol 15: 157. http://doi.org/10.15171/ijb.1567

Kang MH, Reynolds CP (2009) Bcl-2 inhibitors: targeting mitochondrial apoptotic pathways in cancer therapy. Clin Cancer Res 15: 11261132. https://doi.org/10.1158/1078-0432.CCR-08-0144

Kim J-H, Jung S-H, Yang Y-I, Ahn J-H, Cho J-G, Lee K-T, Baek N-I, Choi J-H (2013) Artemisia leaf extract induces apoptosis in human endometriotic cells through regulation of the p38 and NFxB pathways. J Ethnopharmacol 145: 767-775. https://doi.org/10.1016/j. jep.2012.12.003

Kumar B, Kalvala A, Chu S, Rosen S, Forman SJ, Marcucci G, Chen C-C, Pullarkat V (2017) Antileukemic activity and cellular effects of the antimalarial agent artesunate in acute myeloid leukemia. Leukemia Res 59: 124-135. http://doi.org/10.1016/j.leukres.2017.05.007

Leibowitz B, Yu J (2010) Mitochondrial signaling in cell death via the Bcl-2 family. Cancer Biol Therap 9: 417-422. https://doi.org/10.4161/ cbt.9.6.11392

Luo Y, Chen X, Luo L, Zhang Q, Gao C, Zhuang X, Yuan S, Qiao $T$ (2018) [6]-Gingerol enhances the radiosensitivity of gastric cancer via G2/M phase arrest and apoptosis induction. Oncol Rep 39: 2252-2260. https://doi.org/10.3892/or.2018.6292

Madungwe NB, Feng Y, Lie M, Tombo N, Liu L, Kaya F, Bopassa JC (2018) Mitochondrial inner membrane protein (mitofilin) knockdown induces cell death by apoptosis via an AIF-PARP-dependent mechanism and cell cycle arrest. Am J Physiol Cell Physiol 315: C28C43. https://doi.org/10.1152/ajpcell.00230.2017

Mignotte B, Vayssiere J-L (1998) Mitochondria and apoptosis. Eur J Biochem 252: 1-15. https://doi.org/10.1046/j.1432-1327.1998.2520001.x

Namboodiripad PA (2014) A review: Immunological markers for malignant salivary gland tumors. J Oral Biol Craniofacial Res 4: 127-134. https://doi.org/10.1016/j.jobcr.2014.05.003

NavaneethaKrishnan S, Rosales JL, Lee K-Y (2019) ROS-mediated cancer cell killing through dietary phytochemicals. Oxidative Med Cell Longevity 2019. https://doi.org/10.1155/2019/9051542

Nayak D, Amin H, Rah B, ur Rasool R, Sharma D, Gupta AP, Kushwaha M, Mukherjee D, Goswami A (2015) A therapeutically relevant, 3, 3'-diindolylmethane derivative NGD16 attenuates angiogenesis by targeting glucose regulated protein, $78 \mathrm{kDa}$ (GRP78). Chem-Biol Inter 232: 58-67. https://doi.org/10.1016/j.cbi.2015.03.008

Nayak N, Mishra M (2020) Estimation of Oxidative Stress and Survivorship in Drosophila. In Fundamental Approaches to Screen Abnormalities in Drosophila. Springer, 123-134. https://doi.org/10.1007/9781-4939-9756-5_11

Pattingre S, Tassa A, Qu X, Garuti R, Liang XH, Mizushima N, Packer M, Schneider MD, Levine B (2005) Bcl-2 antiapoptotic proteins inhibit Beclin 1-dependent autophagy. Cell 122: 927-939. https:// doi.org/10.1016/j.cell.2005.07.002

Rah B, Amin H, Yousuf K, Khan S, Jamwal G, Mukherjee D, Goswami A (2012) A novel MMP-2 inhibitor 3-azidowithaferin A (3-azidoWA) abrogates cancer cell invasion and angiogenesis by modulating extracellular Par-4. PloS One 7: e44039. https://doi.org/10.1371/ journal.pone.0044039

Rah B, Rasool R ur, Navak D, Yousuf SK, Mukherjee D, Kumar LD, Goswami A (2015a) PAWR-mediated suppression of BCL2 promotes switching of 3-azido withaferin A (3-AWA)-induced autophagy to apoptosis in prostate cancer cells. Autophagy 11: 314-331. https://doi.org/10.1080/15548627.2015.1017182

Rah B, Nayak D, Rasool R, Chakraborty S, Katoch A, Amin H, Goswami A (2016) Reprogramming of molecular switching events in upr driven er stress: scope for development of anticancer therapeutics. Curr Mol Med 16: 690-701. https://doi.org/10.2174/156652401 6666160829152658.

Rah B, Lone SH, Rasool RU, Faroog S, Navak D, Chikan NA, Chakraborty S, Behl A, Mondhe DM, Goswami A (2015b) Design and synthesis of antitumor heck-coupled Sclareol analogues: modulation of BH3 family members by SS-12 in autophagy and apoptotic cell death. J Med Chem 58: 3432-3444. https://doi.org/10.1021/ jm501942m

ur Rasool R, Rah B, Amin H, Nayak D, Chakraborty S, Rawoof A, Mintoo MJ, Yousuf K, Mukherjee D, Kumar LD (2016) Corrigendum: Dual modulation of Ras-Mnk and PI3K-AKT-mTOR pathways: A Novel c-FLIP inhibitory mechanism of 3-AWA mediated translational attenuation through dephosphorylation of eIF4E. Sci Rep 6. https://doi.org/10.1038/srep21054

Rigo A, Vinante F (2016) The antineoplastic agent $\alpha$-bisabolol promotes cell death by inducing pores in mitochondria and lysosomes. Apoptosis 21: 917-927. https://doi.org/10.1007/s10495-016-1257-y

Ryter SW, Kim HP, Hoetzel A, Park JW, Nakahira K, Wang X, Choi AM (2007) Mechanisms of cell death in oxidative stress. Antioxidants Redox Signal 9: 49-89. https://doi.org/10.1089/ars.2007.9.49

Sharma DK, Rah B, Lambu MR, Hussain A, Yousuf SK, Tripathi AK, Singh B, Jamwal G, Ahmed Z, Chanauria N (2012) Design and synthesis of novel N, N'-glycoside derivatives of 3, 3'-diindolylmethanes as potential antiproliferative agents. MedChemComm 3: 1082-1091. https://doi.org/10.1039/C2MD20098H

Sinha S, Mishra P, Amin H, Rah B, Nayak D, Goswami A, Kumar N, Vishwakarma R, Ghosal S (2013) A new cytotoxic quinolone alkaloid and a pentacyclic steroidal glycoside from the stem bark of Crataeva nurvala: Study of anti-proliferative and apoptosis inducing property. Eur J Med Chem 60: 490-496. https://doi.org/10.1016/j. ejmech.2012.12.017

Skálová A, Stenman G, Simpson RH, Hellquist H, Slouka D, Svoboda T, Bishop JA, Hunt JL, Nibu K-I, Rinaldo A (2018) The role of molecular testing in the differential diagnosis of salivary gland carcinomas. Am J Surgical Pathol 42: e11-e27. https://doi.org/10.1097/ PAS.0000000000000980

Şoica C, Voicu M, Ghiulai R, Dehelean C, Racoviceanu R, Trandafirescu C, Roșca O-J, Nistor G, Mioc M, Mioc A (2020) Natural compounds in sex hormone-dependent cancers: the role of triterpenes as therapeutic agents. Frontiers Endocrinol 11. https://doi. org/10.3389/fendo.2020.612396

Swargiary G, Rawal M, Singh M, Mani S (2020) Molecular approaches to screen bioactive compounds from medicinal plants. In Plant-derived Bioactives. 1-32, Springer

Tagscherer KE, Fassl A, Campos B, Farhadi M, Kraemer A, Böck BC, Macher-Goeppinger S, Radlwimmer B, Wiestler OD, Herold-Mende C (2008) Apoptosis-based treatment of glioblastomas with ABT737, a novel small molecule inhibitor of $\mathrm{Bcl}-2$ family proteins. Oncogene 27: 6646-6656. https://doi.org/10.1038/onc.2008.259

Thangam R, Senthilkumar D, Suresh V, Sathuvan M, Sivasubramanian S, Pazhanichamy K, Gorlagunta PK, Kannan S, Gunasekaran P, Rengasamy R (2014) Induction of ROS-dependent mitochondriamediated intrinsic apoptosis in MDA-MB-231 cells by glycoprotein from Codium decorticatum. I Agric Food Chem 62: 3410-3421. https:// doi.org/10.1021/if405329e

Tin AS, Sundar SN, Tran KQ, Park AH, Poindexter KM, Firestone GL (2012) Antiproliferative effects of artemisinin on human breast cancer cells requires the downregulated expression of the E2F1 transcription factor and loss of E2F1-target cell cycle genes. Anti-Cancer Drugs 23: 370-379. https://doi.org/10.1097/ CAD.0b013e32834f6ea8

Viktorsson K, Lewensohn R, Zhivotovsky B (2005) Apoptotic pathways and therapy resistance in human malignancies. Adv Cancer Res 94: 143-196. https://doi.org/10.1016/S0065-230X(05)94004-9

Wang L, Li J, Shi X, Li S, Tang PM-K, Li Z, Li H, Wei C (2019) Antimalarial Dihydroartemisinin triggers autophagy within HeLa cells of human cervical cancer through Bcl-2 phosphorylation at Ser70. Phytomedicine 52: 147-156. https://doi.org/10.1016/j. phymed.2018.09.221

Wong YK, Xu C, Kalesh KA, He Y, Lin Q, Wong WF, Shen H-M, Wang J (2017) Artemisinin as an anticancer drug: Recent advances 
in target profiling and mechanisms of action. Med Res Rev 37: 1492 1517. https://doi.org/10.1002/med.21446

Wu C-C, Bratton SB (2013) Regulation of the intrinsic apoptosis pathway by reactive oxygen species. Antioxidants Redox Signal 19: 546558. https://doi.org/10.1089/ars.2012.4905

Wu Z, Wang H, Fang S, Xu C (2018) Roles of endoplasmic reticulum stress and autophagy on $\mathrm{H}_{2} \mathrm{O}_{2}$-induced oxidative stress injury in HepG2 cells. Mol Med Rep 18: 4163-4174. http://doi.org/10.3892/ mmr.2018.9443

Wysocki PT, Izumchenko E, Meir J, Ha PK, Sidransky D, Brait M (2016) Adenoid cystic carcinoma: emerging role of translocations and gene fusions. Oncotarget 7: 66239. https://doi.org/10.18632/oncotarget.11288

Xia S, Miao Y, Liu S (2018) Withaferin A induces apoptosis by ROSdependent mitochondrial dysfunction in human colorectal cancer cells. Biochem Biophys Res Commun 503: 2363-2369. https://doi. org/10.1016/j.bbrc.2018.06.162

Xie X, Clausen OPF, Angelis PD, Boysen M (1999) The prognostic value of spontaneous apoptosis, Bax, Bcl-2, and p53 in oral squamous cell carcinoma of the tongue. Cancer: Inter Int Am Cancer Soc 86: 913-920. https://doi.org/10.1002/(sici)10970142(19990915)86:6<913::aid-cncr4>3.0.co;2-a

Yamamoto T, Hsu S, Lewis J, Wataha J, Dickinson D, Singh B, Bollag WB, Lockwood P, Ueta E, Osaki T (2003) Green tea polyphenol causes differential oxidative environments in tumor versus normal epithelial cells. I Pharmacol Exp Therap 307: 230-236. https://doi. org/10.1124/ipet.103.054676

Zilla MK, Nayak D, Amin H, Nalli Y, Rah B, Chakraborty S, Kitchlu S, Goswami A, Ali A (2014) 4'-Demethyl-deoxypodophyllotoxin glucoside isolated from Podophyllum hexandrum exhibits potential anticancer activities by altering Chk-2 signaling pathway in MCF-7 breast cancer cells. Chem-Biol Int 224: 100-107. https://doi. org/10.1016/j.cbi.2014.09.022

Zorov DB, Juhaszova M, Sollott SJ (2014) Mitochondrial reactive oxygen species (ROS) and ROS-induced ROS release. Physiol Rev 94: 909-950. https://doi.org/10.1152/physrev.00026.2013 